\title{
Pedological Characterization and Fertility Assessment of Mbimba Substation Soils Under Coffee Production in Mbozi District, Tanzania
}

\author{
Dismas P. Mfaume ${ }^{1 *}$, Balthazar M. Msanya ${ }^{2}$ and John J. Msaky ${ }^{3}$ \\ Researcher ${ }^{1}$ and Professors ${ }^{2-3}$ \\ ${ }^{1}$ Tanzania Coffee Research Institute, Mbozi, P.O. Box 11, Songwe, Tanzania \\ ${ }^{2-3}$ Department of Soil and Geological Sciences, College of Agriculture, Sokoine University of Agriculture \\ P.O. Box 3008, Morogoro, Tanzania
}

\begin{abstract}
Pedological characterization was carried out on soils of Mbimba Mbozi, Tanzania. A representative soil profile (TaCRI-P1) was identified, excavated and described using FAO (2006) Guidelines. Four disturbed soil samples and three undisturbed core samples were taken from the profile horizons for physico-chemical laboratory analysis. The pedon developed under udic moisture and thermic temperature regimes was very deep (>150 cm), well drained and had dark brown to black topsoil colour over dark brown to dark reddish subsoil colour. Soil texture ranged from clay loam to clay. Soil pH was rated as very strong acid to medium (4.73 - 5.98) for all horizons. Organic carbon was low to medium; $N$ was very low to low; CEC was medium to high and exchangeable bases ranged from low to high. Bulk densities were high (2.24 - $2.44 \mathrm{~g} / \mathrm{cc})$ for topsoil and low (0.33 - 0.91) for subsoil. Soil moisture retention properties indicated that surface horizon $(0-5 \mathrm{~cm})$ retained more water followed by intermediate $(45-50 \mathrm{~cm})$ horizon and the subsoil (95-100 cm) respectively. According to USDA Soil Taxonomy and World Reference Base for Soil Resources, the pedon at Mbimba was classified as Typic Palehumults and as Haplic Alisols, respectively. These taxa reflected properties that may guide on the use and management of soils. Before lime application, the upper two horizons of the pedon had total nitrogen level ranging between $0.04-0.17 \%$, Phosphorus $2.91-4.59 \mathrm{mgkg}^{-1}$, Potassium $2.36-1 \%$, Calcium 2.36 - $2.35 \mathrm{cmol}(+) \mathrm{kg}^{-1}$ and Magnesium $0.71-1.93 \mathrm{cmol}(+) \mathrm{kg}^{-1}$ which were low to medium. Thus, application of inorganic ( $N, P, K-$ rich), $C a+M g$ and organic fertilizers is recommended to increase nutrient availability. Use of $\mathrm{CaMg}\left(\mathrm{CO}_{3}\right)_{2}$ as soil amendment should be taken into consideration to raise soil pH and enhance balanced nutrient availability for coffee growth.
\end{abstract}

Key Words: Soil Characterization, Soil Morphology, Physical Characteristics, Soil Chemical Properties, Soil Classification.

\section{INTRODUCTION}

Characterization of soil properties is fundamental to all soil studies [1]. Complete soil characterization for classification purposes requires that all horizons of a standard soil profile (to a depth of $180 \mathrm{~cm}$ ) be analysed. Results from such an analysis provide information that can give a clear understanding of the origin of such soils, morphology, classification and spatial distribution of soils in an area [2]. Climatic and other ecological characteristics as well as socioeconomic factors are also important elements in land management [3]. Plant nutrients in soils originate from parent materials from which soils were formed through the weathering of rocks and minerals [4]. Soil variability is the result of natural processes and management practices [5]. Natural variability results from complex geological and pedological processes. Soil properties and related site characteristics are important for one to be able to advise both current and future potential land users on how to use the land in the best possible way [2]. Assessment of the potentials and limitations of soils for different land uses provides the basis for formulating appropriate management strategies which target specific management problems to improve crop production and soil and water conservation strategies [6,2]. According to Jenny cited by [7], soil forming factors namely climate, parent material, biota, relief and time influence the morphological, physical, chemical and biological characteristics of soils. Chemical weathering of silicate rocks plays 
a major role in geochemical cycles, particularly in the cycle of $\mathrm{CO}_{2}$. Carbon dioxide is removed from the atmosphere by rock weathering process and is converted to bicarbonate in streams and eventually in oceans. Soil characterization provides better understanding of soil genesis [1]. According to [8], for effective planning for different land uses, pedological characterization provides information related to potentials and constraints of the land. The intensification of agriculture on land requires a thorough knowledge of the soil as a resource and attributes of the land, its potential and constraints for appropriate soil and water management systems [2]. In addition, environmental characteristics (e.g. climate) and socio-economic factors are also important elements in pedological characterization to provide data and knowledge on soil properties related to the site characteristics (slope, soil color, vegetation) [8]. Also, the knowledge of site characterized soil's physical and chemical properties together with other ecological conditions will aid in determining the correct type and amounts of fertilizer to be applied for optimum crop nourishment and production [2]. To carry out specific soil characterization before crop establishment is important, as crop production is a function of soil properties. Soil characterization provides the basic information necessary to create functional soil classification schemes and to assess soil fertility in order to unravel some unique soil problems in an ecosystem [9].

\section{MATERIALS AND METHODS}

\subsection{Description of study sites}

The study was conducted in Mbozi District, Songwe Region Tanzania. The study area is located within latitudes $9^{0} 05$ '35.97'S and $9^{0} 05^{\prime} 13.10^{\prime \prime} \mathrm{S}$ and longitudes $32^{0} 57^{\prime} 14.51$ 'E and $32^{0} 57^{\prime} 22.32$ 'E. The field trial was carried out at Mbimba substation located in Mlowo Ward, Mbimba Village, $2 \mathrm{~km}$ from the headquarters of Mbozi District and Songwe Region along Mbeya - Zambia highway. Figure 1 shows the location of the studied representative soil profile depicted on

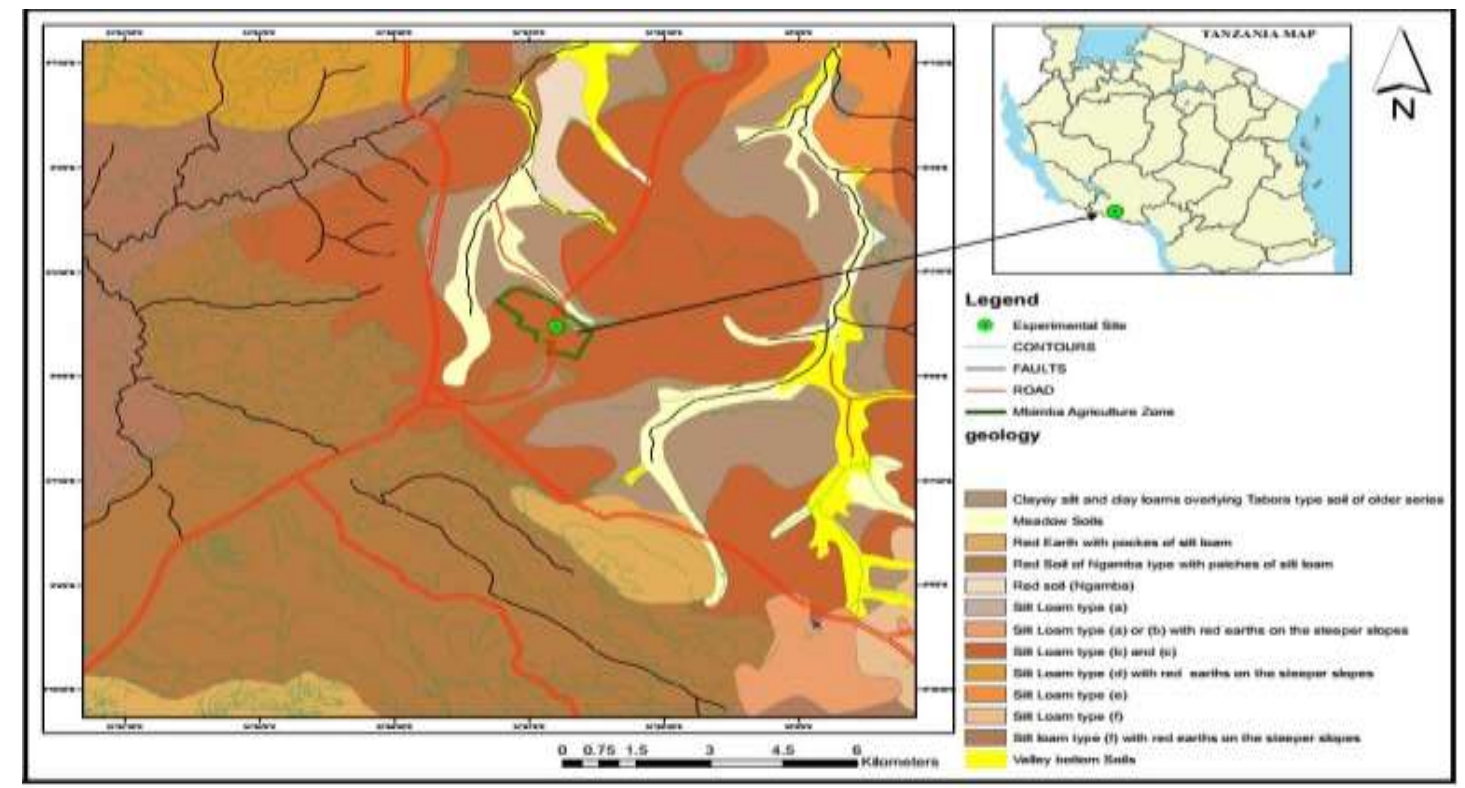

Figure 1. Location of the studied soil profile depicted on the generalized soil map of Mbimba, Mbozi District, Tanzania (Source: Tanzania Government Printer)

the generalized soil map of Mbimba, Mbozi District, Tanzania, which is based on textural differentiation. The average altitude of the study area is 1400 m.a.s.l. The rain season starts between November and December and lasts until May. Mean annual soil temperature at a depth of $50 \mathrm{~cm}$ ranges between 20.9 and $22.5^{\circ} \mathrm{C}$. Soil temperature trends appear to decrease from 2010 to 2017 may be due to increase in soil moisture as a function increase of rainfall. The study area experiences monomodal rainfall pattern with mean annual rainfall ranging between 1000 and $1500 \mathrm{~mm}$ (Fig. 2 and Fig. 3). 


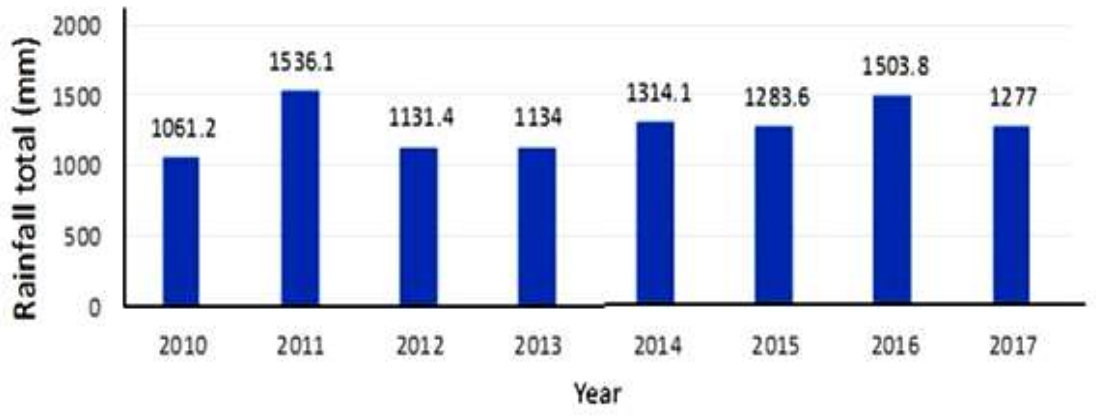

- Rainfall total (mm)

Figure 2. Mean annual rainfall in Mbozi District (2010 - 2017) Source: Mbimba Tanzania Meteorological Agency (TMA) Office

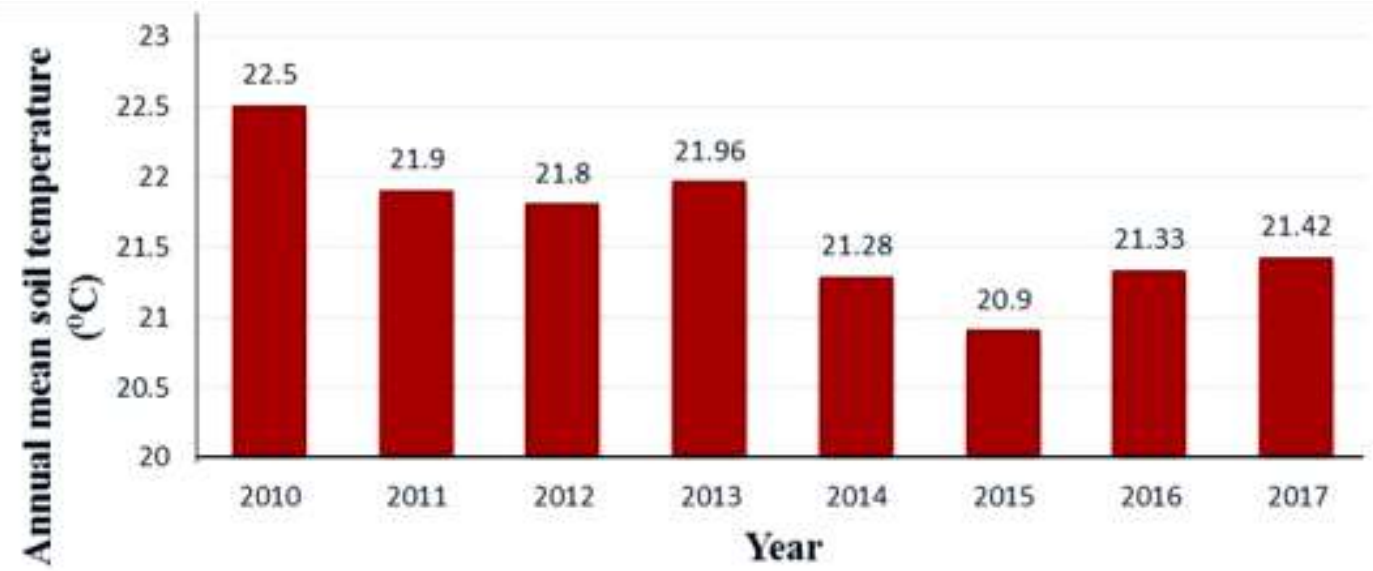

Figure 3. Annual soil temperature $(20 \mathrm{~cm}$ depth) in Mbozi District, Tanzania (2010-2017) Source: Mbimba Agrometeorological Station

\subsection{Field work}

Reconnaissance survey in the study area was carried out based on transect walks, auger observations and soil descriptions to establish the soil settings at the study site on the basis of landforms and other physiographic attributes [10]. Data and information based on landform, soil morphological characteristics, elevation, slope gradient, vegetation and land use/crops were collected from different observation sites that represented the major landforms. The informations were collected and presented in field description forms designed according to the FAO Guidelines for Soil Description [10]. Based on the information gathered during the survey, a single profile for classification of the soil at the study area was established and excavated. Soil horizons were identified, demarcated, described and sampled according to FAO Guidelines for Soil Profile Description [10]. Geo-referencing of the representative profile was done using global positioning system (GPS) Model Garmin etrex 20. Disturbed soil samples were taken from respective genetic horizons of representative profile for laboratory determination of physical and chemical properties. Three undisturbed samples were also taken from the profile for the determination of bulk density and soil moisture characteristics.

\subsection{Laboratory methods}

Undisturbed samples were used for determination of bulk density and moisture retention characteristics. Bulk density was determined by the core method [11]. Pressure plate membrane apparatus [12] was used to determined soil moisture retention characteristics. Disturbed soil samples were air-dried, ground and passed through a 2-mm sieve for physical and chemical soil properties. Particle size distribution was determined by hydrometer method [13] after dispersing soil with sodium hexametaphosphate and textural classes determined using the USDA textural triangle [14]. Soil pH was measured potentiometrically in water and $1 \mathrm{M} \mathrm{KCl}$ at a ratio of 1:2:5 soil-water and soil- $\mathrm{KCl}$ suspensions [15]. Organic carbon was determined by the Walkley and Black wet oxidation method [16] and the organic carbon was converted to organic matter by multiplying by a factor of 1.724 [17]. Total nitrogen was determined by the micro-Kjeldahl digestion - distillation method [18]. Available P was extracted by the Bray and Kurtz 1 method [18]. Cation exchange capacity (CEC soil) was determined by the 1M ammonium acetate saturation method ( $\mathrm{pH}$ 7.0) [19]. Cation exchange capacity of clay (CEC clay) was calculated using the

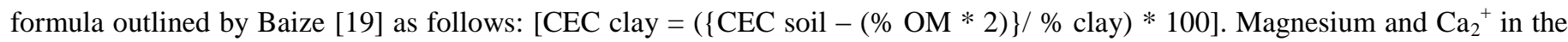


ammonium acetate filtrates were quantified by Atomic Absorption Spectrophotometer while $\mathrm{Na}^{+}$and $\mathrm{K}^{+}$were quantified by the flame photometer, respectively. Total exchangeable base (TEB) was calculated arithmetically as sum of the four exchangeable bases $\left(\mathrm{Ca}^{++}, \mathrm{Mg}^{++}, \mathrm{Na}^{+}\right.$and $\left.\mathrm{K}^{+}\right)$for a given soil sample. Formulas used for the calculation of sodium adsorption ratio, exchangeable sodium percent and base saturation were as given by [20]. Soil extractable $\mathrm{Cu}, \mathrm{Zn}, \mathrm{Fe}$ and Mn were extracted by the DTPA method [21]. The electrical conductivity was determined in 1:2:5 soil:water suspensions, electrometrically (potentiometrically) using an electric conductivity meter [22]. Soil samples for total elemental analysis were prepared through sorting, grinding to powdery form and sieving the powder sample through a sieve of 75 micro millimeters. The powdery samples were exposed to XRF spectrometry for determination of minerals composition in the samples. Total elemental composition was determined by using PAN analytical XRF spectrometry [23].

\subsection{Classification of soils}

Using field and laboratory data, the soil at the study area was classified to family level of USDA Soil Taxonomy [24] and to tier-2 of FAO World Reference Base for Soil Resources [25].

\subsection{Soil fertility evaluation}

Soil fertility characterization was carried out for the purpose of establishing the fertility status of the soil at the study site before application of dolomitic lime. By using an auger, soil was sampled at the depth of $0-30 \mathrm{~cm}$, gathered, mixed thoroughly to constitute composite sample for the fertility evaluation. The samples were taken to SUA soil laboratory for analysis. In the laboratory the soil sample was air dried, ground to break soil aggregates and sieved through 2 mm sieve for comprehensive laboratory analysis, for soil fertility evaluation. The parameters analysed for soil fertility evaluation were; particle size distribution which was determined by the hydrometer method [26], soil $\mathrm{pH}$ was determined electrometrically in $1: 2: 5 \mathrm{soil} \mathbf{0 . 0 1 \mathrm { M } \mathrm { CaCl }} \mathrm{C}_{2}$ suspensions [15], organic carbon by the wet oxidation method [27] and total nitrogen by the micro-Kjeldahl digestion distillation method [28]. Available phosphorus was determined using filtrates extracted by Bray and Kurtz-1 method and determined by spectrophotometer at $884 \mathrm{~nm}$ wavelength following colour developed by molybdenum blue method [29]. Cation exchange capacity (CEC) was determined by the neutral buffered $1 \mathrm{M}$ ammonium acetate saturation method [30]. Calcium and Magnesium in the ammonium acetate filtrates were quantified by Atomic Absorption Spectrophotometer while $\mathrm{K}^{+}$and $\mathrm{Na}^{+}$were quantified by flame photometer. Plant available $\mathrm{Cu}, \mathrm{Zn}, \mathrm{Fe}$ and $\mathrm{Mn}$ were extracted by the DTPA method [21]. The electrical conductivity was determined in 1:2:5 soil:water suspensions, electrometrically (potentiometrically) using an electric conductivity meter [22]. The undisturbed soil samples were used to determine bulk density and the soil moisture characteristics. The bulk density was determined by the core method [11]. Soil moisture retention characteristics were determined using sand kaolin box for low suction values and pressure apparatus for higher suction values [12].

\section{RESULTS AND DISCUSSION}

\subsection{Morphological characteristics of the studied soil profile}

Some important morphological properties of the soil profile at Mbimba TaCRI substation are presented in Table 1. The soil was very deep $(>150 \mathrm{~cm})$, well drained, with gray to very dark gray colour. The soil structure of the topsoil was moderate, medium subangular blocky, while the consistence was very friable when moist, and sticky and plastic when wet. The three bottom horizons $(28-190+\mathrm{cm})$ were very clearly different from the topsoil $(0-18 \mathrm{~cm})$. The soil structures of these horizons were moderate to strong medium subangular blocky, while the consistence was very friable when moist, and very sticky and very plastic when wet. Roots were distributed throughout the profile but highly dense at in topsoil and decreasing with increasing depth. Soil horizon boundaries were quite distinct, ranging mostly from clear to abrupt with either smooth or wavy horizon topography. Few distinct clay cutans, and common distinct clay cutans were observed respectively in the third and fourth horizons affirming the processes of clay eluviation and illuviation as typical pedogenic processes in the studied soil.

Table 1. Key morphological characteristics of the studied soil profile TaCRI-P1

\begin{tabular}{|c|c|c|c|c|c|c|c|}
\hline Horizon & Depth (cm) & Texture & Moist Color ${ }^{1}$ & Consistence $^{2}$ & Structure $^{3}$ & $\begin{array}{l}\text { Other key } \\
\text { pedogenic } \\
\text { features }^{4}\end{array}$ & $\begin{array}{l}\text { Horizon } \\
\text { boundary }\end{array}$ \\
\hline Ap & $0-18$ & Clay & $\mathrm{db}(5 \mathrm{YR} 3 / 2)$ & vfr, s\&p & $\mathrm{m}, \mathrm{m}, \mathrm{sbk}$ & - & cs \\
\hline $\mathrm{Ah}$ & $18-28 / 35$ & Clay & $\mathrm{bl}(5 \mathrm{YR} 2.5 / 1)$ & vfr, s\&p & m-s,sbk & - & $\mathrm{cW}$ \\
\hline Bt1 & $28 / 35-82 / 99$ & Clay & $\operatorname{drb}(5 Y R 3 / 4)$ & vfr, vs\&vp & m-s,sbk & fdcc & $\mathrm{cw}$ \\
\hline Bt2 & $82 / 99-190+$ & Clay & $\mathrm{db}(7.5 \mathrm{YR} 3 / 4)$ & sha, fr, s\&p & m-s,m,sbk & cdcc & - \\
\hline
\end{tabular}

${ }^{1}$ Soil color: db=dark brown, bl=black, drb=dark reddish brown 
${ }^{2}$ Consistence: fr=friable, vfr = very friable, $\mathrm{s} \& \mathrm{p}=$ sticky and plastic, $v \mathrm{~s} \& \mathrm{vp}=$ very sticky and very plastic, sha $=$ slightly hard

${ }^{3}$ Structure: $\mathrm{m}, \mathrm{m}, \mathrm{sbk}=$ moderate medium subangular blocky, $\mathrm{m}-\mathrm{s}, \mathrm{sbk}=$ moderate to strongsubangular blocky

${ }^{4}$ Other pedogenic features: fdcc=few distinct clay cutans, $c d c c=$ common distinct clay cutans

${ }^{5}$ Horizon boundary: cs=clear smooth, $\mathrm{cw}=$ clear wavy

\subsection{Soil physical characteristics}

Soil physical properties of the horizon soil samples are presented in Table 2.

\subsubsection{Soil particle size distribution and silt/clay ratios}

Tables 2.2 indicate soil particle size distribution and silt/clay ratios. Particle size distribution of the four horizons Ap, Ah, Bt1 and $\mathrm{Bt} 2$ all show clay texture dominance and clay content increased down the profile. The results are similar to those indicated by [31] for soils of Busia County, Western Kenya. This supports the fact that the soils has developed largely under similar soil forming factors and have attained comparable degree of pedogenesis [32]. Silt/clay ratios of the subsoil are lower compared to those of the upper two horizons indicating higher degree of weathering in the subsoil. On the basis of textural class, soils of Mbimba substation indicate good water and nutrient holding capacity that is important for coffee growing. Similarly, [33] indicated that clayey texture is associated with high water retention capacity and high nutrient retention. In Bangladesh and Western Kenya, some researchers observed consistent clay increase with depth as an indication of clay migration [34]. Texture is the most stable physical property which influences other soil properties like soil structure, consistence, soil moisture regime and infiltration rate, runoff rate, erodibility, workability, permeability, root penetrability and fertility of the soil [20]. Textural data of the studied pedons are presented in Table 2 .

Table 2. Selected physical properties of the studied pedon TaCRI-P1 in Mbimba Substation, Mbozi, Tanzania

\begin{tabular}{|c|c|c|c|c|c|c|c|c|c|c|}
\hline \multirow[t]{2}{*}{ Horizon } & \multirow[t]{2}{*}{ Depth (cm) } & Sand & Clay & Silt & \multirow[t]{2}{*}{$\begin{array}{l}\text { Textural } \\
\text { class }\end{array}$} & \multirow[t]{2}{*}{$\begin{array}{l}\text { Silt/clay } \\
\text { ratio }\end{array}$} & \multirow[t]{2}{*}{$\begin{array}{c}\text { BD } \\
\mathrm{Mg} \mathrm{m}^{-3}\end{array}$} & \multirow[t]{2}{*}{$\begin{array}{l}\text { Porosity } \\
(\%)\end{array}$} & \multirow[t]{2}{*}{$\begin{array}{l}\text { PR } \\
\text { (MPa) }\end{array}$} & \multirow[t]{2}{*}{$\begin{array}{l}{ }^{\#} \mathbf{P A W} \\
(\mathbf{m m})\end{array}$} \\
\hline & & \multicolumn{3}{|c|}{$\%$} & & & & & & \\
\hline Ap & $0-18$ & 30.2 & 47.1 & 22.6 & $\mathrm{C}$ & 0.48 & 0.97 & 63.4 & 1.01 & 14.4 \\
\hline $\mathrm{Ah}$ & $18-28 / 35$ & 30.2 & 48.1 & 21.6 & $\mathrm{C}$ & 0.45 & nd & nd & 0.79 & nd \\
\hline Bt1 & $28 / 35-82 / 99$ & 22.2 & 60.1 & 17.6 & $\mathrm{C}$ & 0.29 & 1.15 & 56.6 & 0.84 & 30.72 \\
\hline $\mathrm{Bt} 2$ & $82 / 99$ - 190+ & 26.2 & 54.1 & 19.6 & $\mathrm{C}$ & 0.36 & 0.95 & 64.2 & 2.21 & 54.60 \\
\hline
\end{tabular}

$\mathrm{C}=$ clay $\quad{ }_{\mathrm{PAW}}=\quad$ Plant available water $\quad \mathrm{nd}=$ not determined $\quad \mathrm{PR}=$ Penetration resistance

Note:

1. Porosity $=\left(1-(\right.$ Bulk density/Particle density) $\mathrm{x} 100)$ assuming particle density $2.65 \mathrm{~g} / \mathrm{cm}^{3}$

2. $\mathrm{PAW}(\mathrm{mm})=10\left[\right.$ Moisture at Field Capacity $(\mathrm{FC})$ in $\mathrm{m}^{3} / \mathrm{m}^{3}-$ Moisture at Permanent Wilting Point $(\mathrm{PWP})$ in $\mathrm{m}^{3} / \mathrm{m}^{3} \mathrm{x}$ horizon depth in $\mathrm{cm}]$

3. PR $\left(\mathrm{kg} / \mathrm{cm}^{2}\right)$ based on penetrometer model: DIK-5551 Japanese (Daiki Rika Kogyo Co. LTD. = $(100 \mathrm{x}$ penetrometer reading $(\mathrm{r}) / 0.7952(40-\mathrm{r})^{2}$ where $\mathrm{r}$ is in $\mathrm{mm}$

4. $\quad \mathrm{PR}(\mathrm{MPa})=\mathrm{PR}\left(\mathrm{kg} / \mathrm{cm}^{2}\right) \times 0.0981$

\subsubsection{Bulk density and porosity}

Bulk density (BD) is an important parameter for the description of soil quality and ecosystem function. The upper two horizons of Mbozi soils have BD value of $0.97 \mathrm{~g} \mathrm{~cm}^{-3}$ while subsoil BD values of Mbimba ranged from $0.95-1.15 \mathrm{gcm}^{-3}$. Critical levels of BD for clays are 1.0 to $1.60 \mathrm{gcm}^{-3}$ and for sands is 1.20 to $1.80 \mathrm{gm}^{-3}$ with potential root restriction occurring at $\geq 1.40 \mathrm{gcm}^{-3}$ for clay; and $\geq 1.60 \mathrm{gcm}^{-3}$ for sands [35. [37] indicated that BD critical range for clay soils is from 1.46 to $1.63 \mathrm{gcm}^{-3}$ and potential root restriction occurs at values $\geq 1.4 \mathrm{~g} \mathrm{~cm}^{-3}$ for clays. Similarly, [36] pointed out that BD of 1.46 to $1.63 \mathrm{gcm}^{-3}$ for silts and clays, may impose many stresses such as mechanical resistance, poor aeration and changes in hydrological system in soil. Mbimba soils have low BD values according to [20] who stipulated that cultivated soils have bulk density ranging from 0.9 to $1.4 \mathrm{gcm}^{-3}$ which would favour the growth of coffee plants. The Mbimba soil bulk density values are similar to those reported by [31] for soils of Western Kenya. Low bulk density values may be attributed to presence of organic matter and/or the presence of allophane which contribute to formation of porous soil structure [37,38]. Bulk density affects infiltration, rooting depth, available water capacity, soil porosity, plant nutrient availability and soil microbial activity which influence key soil processes and productivity [39]. Low bulk density facilitates water infiltration, high soil microbial activity and easy plant root penetration for nutrients and water extraction. [40] indicated that, top soils that are loose facilitate root growth and easy tillage. The relatively higher bulk density in the mid horizon of studied soil profile may be due to lower organic carbon and organic matter content [41]. According to [42], as quoted by [20], bulk density of 1.46 to 1.63 for silts and clays may cause hindrance to root penetration. [11] pointed out that, bulk density is influenced by the amounts of organic matter in the soil. The bulk density determines the magnitude of particle to particle contacts and how they influence the total porosity and available soil moisture [20]. Total porosity (\% vol/vol) of the 
studied soils shows that topsoil has porosity of 63.4 while subsoil has porosity ranging between 56.6 to $64.2 \%$. [20] pointed out that, total porosity of soils usually lies between 30 and $70 \%$ and may be used as a very general indication of degree of compaction in the same way as bulk density is used. The Ap horizon had higher porosity value than Bt1 horizon (Table 2). This may be due to higher organic matter in Ap horizon than in Bt1 horizon.

\subsubsection{Penetration resistance}

Table 2 presents the penetration resistance values of the studied pedon. Topsoil penetration resistance values of the studied pedons ranged from $0.79-1.01 \mathrm{MPa}$ while those of subsoils ranged from $0.84-2.21 \mathrm{MPa}$. This indicates low soil compaction in topsoil which may be attributed by presence of organic matter. According to [43, 31], penetration resistance of <2.94 MPa, implies less possibility of soil compaction in the profile horizon and hence this is not likely to impair plant growth and development.

\subsubsection{Soil moisture retention characteristics}

Soil water retention curves of the studied profile are presented in Figure 4, showing amounts of water retained by the soil at various suction pressures for three sections of the studied soil profile i.e. surface horizon $(0-5 \mathrm{~cm})$, intermediate horizon $(45-50$ $\mathrm{cm})$ and subsurface horizon $(95-100 \mathrm{~cm})$. Surface horizon retained less water than other horizons under all suction pressures. The trend of moisture retained at various suction pressures was as follows: surface soil < intermediate < subsurface soil. This is in line with the fact that clay content increased with depth (Table 2). Similar trend was observed for other soils in Tanzania [44]. When clay content increases, ability of soil to retain water increases at any particular matric potential and the more gradual is the slope of the curves [11, 45]. Moreover, the results correspond to those of [20,45] depicting that clay soils, generally show slow and regular decrease in water content with increased suction pressure. According to [46], soil particle size distribution, organic matter and soil type influence the variation of available moisture content in the soil. Plant available water (PAW) in the studied soil profile appears to increase with increasing depth (Table 2). This is attributed to increase of clay content down the profile.

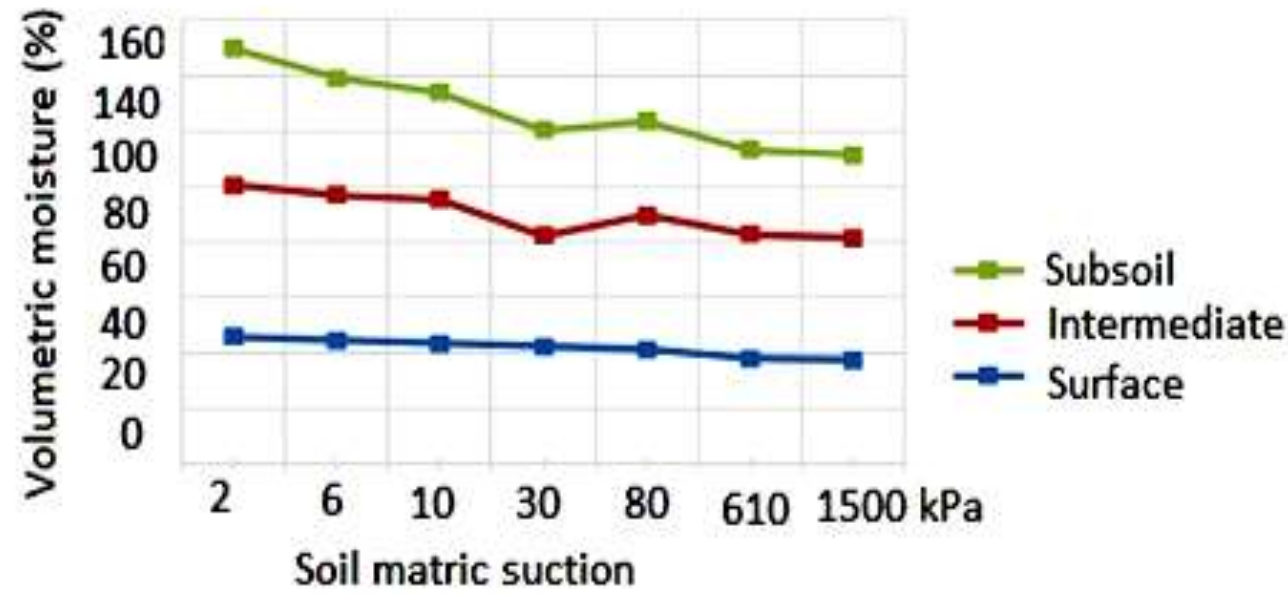

Figure 3. Soil moisture characteristics curve of the studied soil in Mbozi District, Tanzania

\subsection{Chemical properties}

\subsubsection{Soil reaction $(\mathbf{p H})$}

Soil $\mathrm{pH}$ is an important chemical property because of its influence on nutrient availability [47]. According to [48], coffee plants thrive well in soils of $\mathrm{pH} 5.6$ to 6.6. Furthermore, [19] pointed out that most plants thrive well in soils with pH 6.5 - 7.5. From this point of view, the studied soils with $\mathrm{pH}$ (water) values ranging from 5.8 to about 6.0 (Table 3) may present some limitations to crop production. According to [49], low pH may adversely affect availability of various plant nutrients such as phosphorus and basic cations like $\mathrm{Ca}$ and $\mathrm{Mg}$. According to [50], the $\mathrm{pH}$ values observed in the studied soil profile have been rated as medium acid. Such values are likely going to trigger nutrient imbalances, toxicity and nutrient unavailability. Low $\mathrm{pH}$ in horizons could be attributed to the relatively high leaching of $\mathrm{Na}, \mathrm{Ca}$, and $\mathrm{Mg}$ ions which is due to high rainfall and nutrient mining/uptake by plants. According to [51] low soil $\mathrm{pH}$ values have potential to cause toxicity problems and deficiency of some essential plant nutrients as well as affect soil microbial activities due to high concentration of $\mathrm{H}^{+}$and $\mathrm{Al}^{3+}$. Soil $\mathrm{pH}<5.5$ could also cause dissolution of aluminum and iron minerals which precipitates with phosphorus effectively causing its fixation.

\subsubsection{Available phosphorus}

The results in Table 3 indicate that available phosphorus decreased down the pedon. According to [52], phosphorus is highly affected by $\mathrm{pH}$. Phosphorus availability decreases as soils become acidic. In the Table 3 , $\mathrm{P}$ concentration ranges between 0.11 and 
$4.59 \mathrm{mgkg}^{-1}$. The upper two layers of the pedon have phosphorus content ranging between 2.91 and $4.59 \mathrm{mgkg}^{-1}$. According to [20], available P (Bray-Kurtz 1) at $<7 \mathrm{mgkg}^{-1}$ is considered as low phosphorus. Furthermore, concentration of $\mathrm{P}<3$ and $3-6.5$ ppm is considered as acutely deficient and deficient respectively.

Table 3. Soil reaction and selected macronutrients

\begin{tabular}{|l|l|l|l|l|l|l|l|l|}
\hline Horizon & Depth $(\mathbf{c m})$ & \multicolumn{2}{|c|}{ pH 1:2:5 } & OC & OM & TN & C/N & Avail P mg/kg \\
\hline & & $\mathbf{H}_{\mathbf{2}} \mathbf{O}$ & KCl & \multicolumn{3}{|c|}{ \% } & & Bray and Kurtz 1 \\
\hline Ap & $0-18$ & 5.82 & 4.86 & 2.44 & 4.21 & 0.17 & 14 & 4.59 \\
\hline Ah & $18-28 / 35$ & 5.79 & 4.84 & 2.04 & 3.51 & 0.15 & 14 & 2.91 \\
\hline Bt1 & $28 / 35-82 / 99$ & 5.96 & 4.99 & 0.91 & 1.57 & 0.07 & 13 & 0.43 \\
\hline Bt2 & $82 / 99-190+$ & 5.98 & 5.03 & 0.33 & 0.57 & 0.04 & 8 & 0.11 \\
\hline
\end{tabular}

According to [53], an available $\mathrm{P}$ level of $15 \mathrm{mg} / \mathrm{kg}$ is generally considered as the critical level below which $\mathrm{P}$ deficiency symptoms are likely to occur in many crops. Trends of available $\mathrm{P}$ in the studied soil decreases with increasing profile depth. The possible cause can be due to decrease in organic matter content with depth because soil organic matter plays a key role in $\mathrm{P}$ availability due to its ability to coat aluminium and iron oxides, which reduces $\mathrm{P}$ sorption [54]. Similarly, low soil pH observed may provoke the reaction of $\mathrm{P}$ iron $(\mathrm{Fe})$ and aluminium $(\mathrm{Al})$ thereby producing insoluble $\mathrm{Fe}$ and $\mathrm{Al}$ phosphates that are not readily available for plant uptake [54] as shown in the equation below:

$\mathrm{Al}^{3+}+\mathrm{H}_{2} \mathrm{PO}_{4}^{-}+\mathrm{H}_{2} \mathrm{O} \longrightarrow \mathrm{Al}(\mathrm{OH}) \mathrm{P}_{2} \mathrm{PO}_{4}+\mathrm{H}^{+}$.

The presence of chemically active oxides/hydroxide can also fix $\mathrm{P}$ as follows:
$\mathrm{Al}(\mathrm{OH})_{3}+\mathrm{H}_{2} \mathrm{PO}_{4}^{-} \longrightarrow \mathrm{Al}(\mathrm{OH}) \mathrm{H}_{2} \mathrm{PO} 4+\mathrm{OH}^{-}$ (2) and
$\mathrm{Fe}(\mathrm{OH})_{2}+\mathrm{H}_{2} \mathrm{PO}_{4}^{-} \longrightarrow \mathrm{Fe}(\mathrm{OH}) \mathrm{H}_{2} \mathrm{PO}_{4}{ }^{-}+\mathrm{OH}^{-}$

\subsubsection{Organic carbon, organ matter, total nitrogen and carbon/nitrogen ratio}

The two-subsoil horizons have very low to low organic carbon content ranging from 0.33 - 0.91. According to [55], organic carbon less than 0.6 is considered as very low and $0.60-1.25$ as low. The OM content in the studied pedon ranged from low to medium (0.6 - 4.2\%) and decreased down the profile (Table 3). OM level in the soil is strongly correlated with the soil's CEC, and is a source of many plant nutrients, particularly nitrogen [38]. Soil organic matter enhances soil water retention because of its hydrophilic nature and its positive influence on soil structure [56]. Total nitrogen level as shown in Table 3 ranges between 0.04 and $0.17 \%$. Total nitrogen levels of less than $0.2 \%$ and organic carbon values below $0.6 \%$ are considered low for agricultural activities [20]. According to [2], low $\mathrm{N}$ content in the soil can be supplemented by $\mathrm{N}$ fertilizer application for optimal plant growth. The low soil $\mathrm{pH}$ also may be the cause for low nitrogen content as low $\mathrm{pH}$ affects microbial activity in the soil and the consequence is low organic matter breakdown [20]. $\mathrm{C} / \mathrm{N}$ ratios in the studied soil ranged from 8 - 14 and there was a general trend of narrowing of the ratios with increasing depth. According to [57], the $\mathrm{C} / \mathrm{N}$ ratios in the upper $100 \mathrm{~cm}$ were rated to be of moderate to good quality whereas those in the deeper subsoil were rated to be of poor quality, although [57] indicated that, C:N ratio of 10:1 indicates good quality organic material, they cautioned that $\mathrm{C}: \mathrm{N}$ ratio might not be a good indicator of soil fertility, and thus encouraged use of individual $\mathrm{C}$ and $\mathrm{N}$ values instead.

\subsubsection{Exchangeable Ca, Mg, $\mathrm{Na}, \mathrm{K}$ and CEC}

The results on exchangeable cations of the studied soil profile are given in Table 4. Exchangeable cations were rated as very low to high for Calcium, while Magnesium was rated as medium and Potassium rated as medium to very high. Exchangeable cations levels were variable within the studied pedon with a general tendency for $\mathrm{Mg}$ and $\mathrm{K}$ to increase down the profile. [9] made similar observations and pointed out that exchangeable cations increase down the profile for highly leached soils. Amount of exchangeable sodium in Mbimba soils varied from 0.03 to $0.19 \mathrm{cmol}(+) \mathrm{kg}^{-1}$ (Table 4). According to [48], sodium concentration levels $<0.1$ and $0.10-0.30 \mathrm{cmol}(+) \mathrm{kg}^{-1}$ are considered as very low and low respectively. Thus, the upper horizon (Ap) had very low sodium while the $(\mathrm{Ah})$ horizon had low sodium concentration which increases down the profile indicating leaching of Na. According to [48], soils with ESP $<3$ is considered as non-sodic and soils with ESP 6 - 10 considered as slightly sodic. Thus, the soils of Mbimba Mbozi are considered as not salt-affected. Potassium level ranged between 0.05 and 1 indicating low potassium concentration while the optimal concentration for optimal arabica growth is $1.21-2.0 \mathrm{mgkg}^{-1}$ [20]. Furthermore, in all horizons, concentration of cations increased down the profile which may be due to leaching of these cations. Levels of exchangeable cations have direct implications on the cation exchange capacity (CEC), soil $\mathrm{pH}$ and finally plant nutrient imbalances, unavailability and nutrient induced deficiencies. For example, $\mathrm{Mg}$ acts as a phosphorus carrier in plants and therefore, $\mathrm{P}$ uptake is influenced by exchangeable $\mathrm{Mg}$ [8]. Cation Exchange Capacity (CEC) in the studied soil profile was rated as medium to high (24 - 27 cmol(+) kg). High CEC is due to clay content in the pedon [58]. The [10] quotes values of $8-10 \mathrm{cmol}^{(+)} \mathrm{kg}^{-1}$ of soil as indicative 
for minimum value in the top $30 \mathrm{~cm}$ of the soil for satisfactory crop production, provided other factors remain favourable. According to [10], any value $<4 \mathrm{cmol}(+) \mathrm{kg}^{-1}$ soil (measured at the $\mathrm{pH}$ of the soil) indicates a degree of infertility normally not suitable for crop production. In the Table 4, percent base saturation (BS) varied from 19.62 to $30.54 \mathrm{cmolkg}^{-1}$ and decreased with depth. According to [20], BS\% $<20$ is considered as low, between 20 and $60 \%$ medium and $>60 \%$ high. Generally, the soil of Mbimba Mbozi was rated to be of low fertility. [20] pointed out that, availability of nutrients for uptake by plants depends not only upon absolute levels of nutrients but also on the nutrient ratios. $\mathrm{Ca} / \mathrm{Mg}$ ratios in the studied soil profile ranged between 0.04 and 3.3 for all horizons while $\mathrm{Ca} / \mathrm{Mg}$ ratios of 2 to 4 are considered as favourable for most crop plants to grow [59, 8]. The upper two horizons (Ap and $\mathrm{Ah}$ ) had $\mathrm{Ca} / \mathrm{Mg}$ ratio between 2.6 - 3.3 implying optimal conditions.

Table 4. Exchangeable bases and nutrient ratios in the studied soil profile TaCRI-P1

\begin{tabular}{|l|c|l|l|l|l|l|l|l|l|}
\hline \multirow{2}{*}{ Site } & Horizon & \multicolumn{6}{|c|}{ Exchangeable bases cmol(+)/kg } & \multirow{2}{*}{ Ba/Mg } \\
\cline { 3 - 9 } & & Ca & Mg & K & Na & CEC & TEB & & \\
\hline Mbimba TaCRI & Ap & 4.59 & 1.41 & 1.3 & 0.03 & 24 & 7.33 & 30.54 & 3.3 \\
\hline & Ah & 4.02 & 1.57 & 0.05 & 0.05 & 25 & 7.21 & 28.84 & 2.6 \\
\hline & Bt1 & 1.95 & 1.63 & 1.86 & 0.1 & 27 & 5.54 & 20.51 & 1.2 \\
\hline & Bt2 & 0.07 & 1.91 & 3.13 & 0.19 & 27 & 5.3 & 19.62 & 0.04 \\
\hline
\end{tabular}

$\mathrm{CEC}=$ Cation exchange capacity, TEB =Total exchangeable bases, $\mathrm{BS}=\mathrm{B}$ ase saturation.

\subsubsection{Micronutrient concentration in the studied soil}

Table 5 presents results on the analysed micronutrients $\mathrm{Cu}, \mathrm{Mn}, \mathrm{Fe}$ and $\mathrm{Zn}$. The results indicate the concentrations of the micronutrients as follows: $\mathrm{Cu}\left(0.04-6.80 \mathrm{mgkg}^{-1}\right), \mathrm{Zn}\left(1.07-5.93 \mathrm{mgkg}^{-1}\right), \mathrm{Mn}\left(21.08-193.03 \mathrm{mgkg}^{-1}\right)$ and Fe $(68.22-101.28$ $\left.\mathrm{mgkg}^{-1}\right)$. According to [57], concentration of micronutrients of $\mathrm{Cu}\left(2-250 \mathrm{mgkg}^{-1}\right), \mathrm{Zn}\left(1-900 \mathrm{mgkg}^{-1}\right), \mathrm{Mn}^{2}\left(20-10000 \mathrm{mgkg}^{-1}\right)$ and $\mathrm{Fe}\left(50-150 \mathrm{mgkg}^{-1}\right)$ are considered as optimal ranges. Thus, the results imply $\mathrm{Cu}$ to be deficient while $\mathrm{Mn}, \mathrm{Fe}$, and $\mathrm{Zn}$ are sufficient. The levels of micronutrients decreased with depth (Table 5). Similarly, [20] pointed out that availability of micronutrients decreases with increase in soil $\mathrm{pH}$. Results in Table 3 indicate that the $\mathrm{pH}$ of surface horizon of the study area is very acidic and the $\mathrm{pH}$ decrease slightly as you move down the profile. [44] pointed out that, $\mathrm{Cu}$ and $\mathrm{Mn}$ are more available at $\mathrm{pH}$ of 5 to 6.5 and decrease when $\mathrm{pH}$ is below 5 or above 6.5 .

Table 5. Micronutrient contents of the studied soil profile TaCRI-P1 in Mbimba Mbozi, Tanzania

\begin{tabular}{|l|l|l|l|c|c|}
\hline Horizon & Depth (cm) & \multicolumn{4}{|c|}{ Micronutrient content $\mathbf{~ m k g}^{-1}$} \\
\hline & & Cu & Zn & Mn & Fe \\
\hline Ah & $10-18$ & 6.80 & 5.93 & 193.03 & 101.28 \\
\hline Ap & $18-28 / 35$ & 2.63 & 3.13 & 82.85 & 97.82 \\
\hline Bt1 & $28 / 35-82 / 99$ & 0.26 & 1.40 & 45.28 & 72.45 \\
\hline Bt2 & $82 / 99-190+$ & 0.04 & 1.07 & 21.08 & 68.22 \\
\hline
\end{tabular}

\subsubsection{Total elemental composition of the studied soil Mbimba Mbozi, Tanzania}

Results on total elemental composition of the studied soil are given in Table 6a. Silica $\left(\mathrm{SiO}_{2}\right)$ is the most abundant oxide ranging from $38.70-45.90 \%$. The high values of $\mathrm{SiO}_{2}$ indicate the existence of amorphous silica [8]. Concentration of $\mathrm{Al}_{2} \mathrm{O}_{3}(20.01-$ $23.08 \%)$ and $\mathrm{Fe}_{2} \mathrm{O}_{3}(19.60-32.20 \%)$ are available in abundance compared to other oxides. The possible reason is the high presence of gibbsite and hematite in the soil [60]. Trends of other oxides i.e $\mathrm{TiO}_{2}$ and $\mathrm{RuO}_{2}$ indicate that their abundance increases down the profile while $\mathrm{MnO}$ and $\mathrm{K}_{2} \mathrm{O}$ decrease down the profile. According to [60], soils in Mbeya have high concentration of $\mathrm{TiO}_{2}$ similar to what is shown in the Table 5. According to [61], terrestrial plants and their associated microbiota, directly affect silicate mineral weathering in several ways: by generation of chelating ligands, by modifying $\mathrm{pH}$ through production of $\mathrm{CO}_{2}$ or organic acids, and by altering the physical properties of a soil.

Concentration of potentially toxic elements in the studied soil profile are indicated in Table 6a. Concentration of $\mathrm{Pb}$ (41 - $49 \mathrm{mg}$ $\left.\mathrm{kg}^{-1}\right), \mathrm{Cr}\left(186-199 \mathrm{mg} \mathrm{kg}^{-1}\right)$ and $\mathrm{Zn}\left(96-155 \mathrm{mg} \mathrm{kg}^{-1}\right)$ found in the studied soil were found within the normal levels that are commonly reported in many soils around the world. According to [62], $\mathrm{Zn}$ concentration of $300 \mathrm{mg} \mathrm{kg}^{-1}$, Ni concentration of 75 $\mathrm{mg} \mathrm{kg}^{-1}$ and $\mathrm{Cu}$ concentration of $140 \mathrm{mgkg}^{-1}$ are considered as maximum limit in the agriculture soils while [63] considered $\mathrm{Pb}$ concentration of $300 \mathrm{mg} \mathrm{kg}^{-1}$ as maximum limit and [64] $600 \mathrm{mg} \mathrm{kg}^{-1}$ is maximum limit for Cr in agriculture soils (Table 6b). The soil profile also had $\mathrm{Cu}$ concentration of $298 \mathrm{mg} \mathrm{kg}^{-1}$ and $\mathrm{Ni}$ concentration of $86 \mathrm{mg} \mathrm{kg}^{-1}$ which are above the maximum limit in 
agriculture soil. The high concentration of these elements may have been contributed by application of pesticides and fungicides in the coffee farm.

The results on total elemental composition of Mbimba Mbozi soil as determined by total XRF are shown in Table 6a. Observed data shows that $\mathrm{K}_{2} \mathrm{O}, \mathrm{MnO}$ and $\mathrm{Bi}$ do not show significant variations in their concentration across the profile which implies there were no losses or gains through leaching or anthropogenic activities. Concentrations of $\mathrm{S}, \mathrm{Cu}, \mathrm{Zn}, \mathrm{CaO}$ and $\mathrm{SiO} 2$ apparently decreased down the soil profile. Higher concentrations of these elements in top soils may be contributed by application of fertilizers, fungicides or pesticides. Similarly, the upper three layers of the profile showed higher concentration of $\mathrm{P}_{2} \mathrm{O}_{5}$ and $\mathrm{RuO}$ than the subsoil. Concentration of $\mathrm{Fe}_{2} \mathrm{O}_{3}$ and $\mathrm{TiO}_{2}$ increased down the profile which is likely due to leaching of some iron oxides and titanium oxides. The concentrations of $\mathrm{Al}_{2} \mathrm{O}_{3}, \mathrm{ZrO}_{2}, \mathrm{Sr}, \mathrm{W}, \mathrm{Ni}, \mathrm{Pb}$ and $\mathrm{V}$ showed inconsistent distribution within the profile. 
International Journal of Advances in Scientific Research and Engineering (ijasre), Vol 5 (10), October-2019

Table 6a. Total chemical composition of the studied soil pedon TaCRI-P1 at Mbimba Mbozi District, Tanzania

\begin{tabular}{|c|c|c|c|c|c|c|c|c|c|c|c|c|c|c|c|c|c|c|c|c|}
\hline Depth (cm) & $\mathrm{Al}_{2} \mathrm{O}_{3}$ & $\mathrm{SiO}_{2}$ & $\mathbf{P}_{2} \mathbf{O}_{5}$ & $\mathbf{K}_{2} \mathbf{O}$ & $\mathrm{CaO}$ & $\mathrm{TiO}_{2}$ & MnO & $\mathrm{F}_{2} \mathrm{O}_{3}$ & $\mathrm{ZrO}_{2}$ & $\mathrm{RuO}_{2}$ & $\mathrm{Sr}$ & $\mathbf{W}$ & Zn & $\mathbf{C u}$ & $\mathbf{N i}$ & $\mathbf{S}$ & $\mathbf{B i}$ & $\mathbf{P b}$ & $\mathrm{Cr}$ & $\mathbf{V}$ \\
\hline & & & & & $\%$ & & & & & & & & $\mathrm{mgkg}^{1}$ & & & & & & & \\
\hline $0-18$ & 22.02 & 45.9 & 0.87 & 3.46 & 1.1 & 2.88 & 1.07 & 19.6 & 0.97 & 0.8 & 34 & 207 & 155 & 298 & 56 & 1079 & 100 & 44 & 187 & 158 \\
\hline $18-28 / 35$ & 22.05 & 45.2 & 0.87 & 3.53 & 1.15 & 2.88 & 1.08 & 20.2 & 1.01 & 0.9 & 35 & 192 & 125 & 126 & 72 & 900 & 99 & 41 & 199 & 133 \\
\hline $28 / 35-82 / 99$ & 20.01 & 38.7 & 0.99 & 3.49 & 0.91 & 3.19 & 1.18 & 26.4 & 1.53 & 1.3 & 30 & 171 & 111 & 98 & 86 & 831 & 101 & 49 & 186 & 157 \\
\hline $82 / 99-190+$ & 23.08 & 43.3 & 0 & 3.29 & 0.68 & 3.04 & 1.05 & 23.1 & 1.15 & 0 & 26 & 208 & 96 & 81 & 56 & 627 & 103 & 38 & 192 & 144 \\
\hline
\end{tabular}

Table $6 a^{1}$ Note: Recovery of reference standard during analysis of soil

\begin{tabular}{|c|c|c|c|c|c|c|c|c|c|c|}
\hline Element Spike & $\mathbf{A l}_{2} \mathbf{O}_{3}$ & $\mathrm{SiO}_{2}$ & $\mathbf{P}_{2} \mathbf{O}_{5}$ & $\mathrm{~K}_{2} \mathrm{O}$ & Cao & $\mathrm{TiO}_{2}$ & MnO & $\mathrm{Fe}_{2} \mathrm{O}_{3}$ & $\mathrm{ZrO}_{2}$ & $\mathrm{RuO}_{2}$ \\
\hline \multicolumn{11}{|c|}{$\%$} \\
\hline Actual value & 21.03 & 45.92 & 0.87 & 3.26 & 1.15 & 2.86 & 0.97 & 19.6 & 80.99 & 0.89 \\
\hline Measured value & 20 & 40.88 & 0.75 & 3.20 & 1.14 & 2.48 & 0.97 & 19.01 & 79.00 & 0.80 \\
\hline
\end{tabular}

Spike=In house reference sample. Most recoveries are close to actual value which is an indication that the analytical procedures were accurate and thus, validated the data presented in this study. For that case the analytical data obtained were presented without any adjustment 
International Journal of Advances in Scientific Research and Engineering (ijasre), Vol 5 (10), October-2019

Table 6b: Concentration of potential toxic elements and their maximum limit

\begin{tabular}{|l|l|l|}
\hline Element & Maximum limit in agriculture soils & References \\
\hline $\mathrm{Zn}$ & $300 \mathrm{mg} \mathrm{kg}^{-1}$ & Commission of the European Communities (1986) \\
\hline $\mathrm{Pb}$ & $300 \mathrm{mg} \mathrm{kg}^{-1}$ & Li et al. (2006) \\
\hline $\mathrm{Cr}$ & $600 \mathrm{mg} \mathrm{kg}^{-1}$ & Pasquini (2006) \\
\hline $\mathrm{Ni}$ & $75 \mathrm{mg} \mathrm{kg}^{-1}$ & Commission of the European Communities (1986) \\
\hline $\mathrm{Cu}$ & $140 \mathrm{mg} \mathrm{kg}^{-1}$ & Commission of the European Communities (1986) \\
\hline
\end{tabular}

3.3.8 Classification of the studied soil at Mbimba, Mbozi, Tanzania

Tables 7 and 8 present the results on the classification of the representative soil profile of the study area using respectively the USDA Soil Taxonomy (to family level) and World Reference Base (WRB) for Soil Resources schemes (to tier 2). Diagnostic horizons and other features were identified in both systems and were then used to classify the soils using the taxonomic keys of the systems. According to USDA Soil Taxonomy umbric epipedon and argillic subsurface horizon were the diagnostic horizons of the soil. These horizons translated respectively into umbric horizon and argic horizon in the WRB system. The soil classified as Gently undulating, very deep, clayey, medium acid, udic, isohyperthermic, Typic Palehumults in the USDA Soil Taxonomy and as Haplic Alisols (Clayic, Cutanic, Hyperdystric, Humic, Profondic) in the WRB for Soil Resources. 
Table 7: Summary of diagnostic features of the studied pedon TaCRI-P1 at Mbimba Substation, Mbozi, and classification according to USDA Soil Taxonomy (Soil (Survey Staff, 2014)

\begin{tabular}{|c|c|c|c|c|c|c|}
\hline Diagnostic horizon(s) & Other diagnostic features & Order & Suborder & Greatgroup & Subgroup & Family \\
\hline $\begin{array}{l}\text { Umbric epipedon; } \\
\text { argillic horizon }\end{array}$ & $\begin{array}{l}\text { Gently undulating (slope 5\%), } \\
\text { very deep, clayey, medium acid, } \\
\text { udic SMR, isohyperthermic } \\
\text { STR, presence of clay cutans }\end{array}$ & Ultisols & Humults & Palehumults & Typic Palehumults & $\begin{array}{l}\text { Gently undulating, very deep, clayey, } \\
\text { medium acid, udic, isohyperthermic, } \\
\text { Typic Palehumults }\end{array}$ \\
\hline
\end{tabular}

Table 8: Summary of diagnostic horizons and features of the studied soils and classification according to World Reference Base for Soil Resources [IUSS Working Group WRB (2015)]

\begin{tabular}{|c|c|c|c|c|c|}
\hline $\begin{array}{l}\text { Diagnostic } \\
\text { horizon(s) }\end{array}$ & $\begin{array}{l}\text { Other diagnostic } \\
\text { features/materials }\end{array}$ & $\begin{array}{l}\text { Reference Soil } \\
\text { Group (Tier 1) }\end{array}$ & Principal Qualifiers & Supplementary qualifiers & Tier 2 Soil name \\
\hline $\begin{array}{l}\text { Umbric horizon; Argic } \\
\text { horizon }\end{array}$ & $\begin{array}{l}\text { Gently undulating (slope } 5 \% \text { ), } \\
\text { very deep, clayey, presence of } \\
\text { clay cutans (cutanic), high } \\
\text { organic matter content }\end{array}$ & Alisols & Haplic & $\begin{array}{l}\text { Clayic, Cutanic, Hyperdystric, } \\
\text { Humic, Profondic }\end{array}$ & $\begin{array}{l}\text { Haplic Alisols (Clayic, } \\
\text { Cutanic, Hyperdystric, Humic, } \\
\text { Profondic) }\end{array}$ \\
\hline
\end{tabular}




\section{CONCLUSIONS}

- The representative soil of the study area under coffee production in Mbimba, Mbozi District was classified as Ultisol (USDA Soil Taxonomy) and Lixisol (WRB).

- The soil is highly weathered, typically very deep, fine textured with moderate to strong subangular blocky structure.

- Generally, the soil has good physical properties.

- The $\mathrm{pH}$ of the soil is acidic due to the high rainfall of the study area

- The soil's essential nutrients N, P K, Ca and Mg are deficient ranging from very low to low.

- Micronutrient levels of $\mathrm{Cu}$ are low particularly in the subsoil, whereas $\mathrm{Zn}, \mathrm{Mn}$ and $\mathrm{Fe}$ levels are adequate.

\section{RECOMMENDATIONS}

- Nitrogen, Phosphorus, Potassium, Calcium and Magnesium that were found to be deficient in the studied area need to be supplemented in form of fertilizers so as to improve arabica coffee growth and productivity in Mbimba Mbozi.

- Soils of Mbimba Mbozi need application of lime in order to raise soil $\mathrm{pH}$ from medium acid to better levels that will favor arabica coffee growth.

\section{ACKNOWLEDGEMENTS}

We wish to acknowledge Tanzania Coffee Research Institute and Dismas Mfaume's Family for jointly funding this work.

\section{REFERENCES}

1. Buol, S. W., Southard, R. J., Graham, R. C. and McDaniel, P. A. (2011). Soil genesis and classification. John Wiley and Sons. [https://www.tib.eu/en/search/id/.../Soil-Genesis-and-Classification- $6^{\text {th }}$-edition] site visited on 10/09/2017.

2. Msanya, B. M., Kaaya, A. K., Araki, S., Otsuka, H. and Nyadzi, G. I. (2003). Pedological characteristics, general fertility and classification of some benchmark soils of Morogoro District, Tanzania. African Journal of Science and Technology 4(2): 101-112. Science and Engineering Series.

3. Uwitonze, P., Msanya, B. M., Mtakwa, P. W., Uwingabire, S. and Sirikare, S. (2016). Pedological Characterization of Soils Developed from Volcanic Parent Materials of Northern Province of Rwanda. Agriculture, Forestry and Fisheries 5(6): 225236.

4. Agricultural Research Council (2009). Republic of South Africa. Department of Education, Soil science course material. Agroecosystems 53: 83-92.

5. Robert, P. (1993). Characterization of soil conditions at the field level for soil specific management. Geoderma 60(1-4): 5772.

6. Muya, E. M., Obanyi, S., Ngutu, M., Sijali, I. V., Okoti, M., Maingi, P. M. and Bulle, H. (2011). The physical and chemical characteristics of soils of Northern Kenya Aridlands: Opportunity for sustainable agricultural production. Journal of Soil Science and Environmental Management 2(1): 1- 8.

7. Munishi, J. A. (2010). Pedological characterisation of soils and assessment of their agricultural potential in selected districts of Mbeya Region, Tanzania. Dissertation for Award of MSc. Degree at Sokoine University of Agriculture, Morogoro,Tanzania. pp. 135.

8. Lufega, S. M. and Msanya, B. M. (2017). Pedological characterization and soil classification of selected soil units of Morogoro District, Tanzania. International Journal of Plant and Soil Science 16(1): 1-12.

9. Tenga, J. J., Msanya, B. M., Semoka, J. M., Semu, E. and Mwango, S. B. (2018). Pedological Characterization and Classification of Some Typical Soils in Three Agro-Ecological Settings of South-Eastern Tanzania. International Journal of Scientific and Engineering Research 9(2): 692-702.

10. FAO, Food and Agriculture Organization of the United Nations (2006). Guidelines for Soil Description. 4th Edn. Food and Agriculture Organization of the United Nations, Rome. 110pp.

11. Blake, G. R. and Hartge, K. H. (1986). Bulk Density. In: Methods of Soil Analysis, Part 1, 2nd Edn. Agronomy Monograph No. 9. (Ed.: Klute, A.). American Society of Agronomy and Soil Science Society of America, Madison, Wisconsin. pp 364376.

12. National Soil Service (NSS), 1990. Laboratory Procedures for Routine Analysis. Agricultural Research Institute, Mlingano, Tanga, Tanzania. 212pp. 
13. Day, P. R. (1965). Particle fractionation and particle size analysis. In: Black C.A, Evans D.D, White J.L, Ensminger L.E and F.E. Clark F.E (Eds.). In: Methods of Soil Analysis: Physical and mineralogical methods, American Society of Agronomy, Madison, Wisconsin. 545-566pp.

14. USDA, United States Department of Agriculture (1965). Textural triangle. United States Department of Agriculture. Soil Science Society of America Proceedings 32: 62-63.

15. Thomas, G. W. (2009). Soil pH and soil acidity. In: Methods of Soil Analysis Part 3 - Chemical Methods: SSSA Book series no. 5. (Edited by Sparks D.L.), Soil Science of America Inc. 5th Edition. pp. 475-490.

16. Nelson, D. W. and Sommers, L. E. (1982). Total carbon, organic carbon and organic matter. In: Methods of Soil Analysis Part 2, 2nd Ed. (eds. Page, A. L., Mil-ler R. H. and Keeney, D. R.) American Society of Agronomy, SSSA Monograph No. 9, Madison, Wisconsin, USA. pp. 539 - 579.

17. Duursma, R. Dawson. (1981). Organic sea surface films, Marine Organic Chemistry. EK Hunter, K. A and Liss, P. S. pp259-298.

18. Moberg, J. P. (2001). Soil and Plant Analysis Manual. (Revised Edition). The Royal Veterinary and Agricultural University, Chemistry Department, Copenhagen, Denmark. 133pp.

19. Baize, D. (1993). Soil Science Analysis. A Guide to Correct Use. John Wiley and Sons Ltd. West Sussex. 192pp.

20. Landon, J. R. (1991). Booker Tropical Soil Manual. A handbook for soil survey and agricultural land evaluation in the tropics and subtropics. Longman Scientific and Technical Publishers, Essex. 474pp.

21. Lindsay, W. L. and Norvell, W. A. (1978). Development of a DTPA soil test for zinc, iron, manganese, and copper 1. Soil Science Society of America Journal 42(3): 421-428.

22. Rhoades, J. D. (1996). Salinity: Electrical conductivity and total dissolved solids. In: Methods of Soil Analysis Part 3: Chemical Methods (Ed.: Sparks, R. L.). Soil Science Society of America, Madison. pp. 417-435.

23. Mobius, J., Lahajnar, N. and Emeis, K. C. (2010). Diagenetic control of nitrogen isotope ratios in Holocene sapropels and recent sediments from the Eastern Mediterranean Sea. Biogeosciences 7: 3901 - 3914.

24. Soil Survey Staff (2014). Keys to Soil Taxonomy. 12th Edn. United States Department of Agriculture, Natural Resources Conservation Service. [https://www.nrcs. usda.gov/wps/PA_NRCS Consumption/download?cid...ext=pdf] site visited on 9th May; 2018.

25. IUSS Working Group WRB (2015). World Reference Base for Soil Resources 2014, Update 2015. International Soil Classification System for Naming Soils and Creating Legends for Soil Maps. World Soil Resources Reports No. 106. FAO, Rome.

26. Gee, G. W. and Bauder J. W. (1986). Particle-size analysis 1. Methods of Soil Analysis Part 1- Physical and mineralogical methods, pp383-411.

27. Nelson, D. W. and Sommers, L. E. (2009). Total carbon, organic carbon, and organic matter. In: Methods of Soil Analysis Part 3: Chemical Methods: SSSA Book series no. 5. (Edited by Sparks D.L.), Soil Science of America Inc. 5th Edition. 961 $1010 \mathrm{pp}$.

28. Bremner, J. M. (2009). Nitrogen-total. In: Methods of Soil Analysis Part 3: Chemical Methods: SSSA Book series no. 5. (Edited by Sparks D.L.), Soil Science of America Inc. 5th Edition. pp. 1085-1121.

29. Bray, R. H. and Kurtz, L. T. (1945). Determination of total, organic, and available forms of phosphorus in soils. Soil Science 59: $39-45$.

30. Somner, M. E. and Miller, W. P. (2009). Cation exchange capacity. In: Methods of Soil Analysis Part 3: Chemical Methods (Ed.: Sparks, R.L.). Soil Science Society of America, Madison. pp.475-490.

31. Kebeney, S. J., Msanya, B. M., Ng'etich, W. K., Semoka, J. M. R. and Serrem, C. K. (2015). Pedological characterization of some typical soils of Busia County, Western Kenya: Soil Morphology, Physico-chemical Properties, Classification and Fertility trends. International Journal of Plant and Soil Science 4(1): 29-44.

32. Soil Survey Staff (1975). Soil Taxonomy: A Basic System of Soil Classification for Making and Interpreting Soil Surveys. US Government Printing Office. 754pp.

33. Akpan-Idiok, A. U. and Ogbaji, P. O. (2013). Characterization and Classification of Onwu River Floodplain Soils in Cross River State, Nigeria. International Journal of Agricultural Research 8: 107-122.

34. Khan, Z. H., Hussain, M. S. and Ottner, F. (2012). Morphogenesis of Three Surface-Water Gley Soils from the Meghna Floodplain of Bangladesh. Dhaka University Journal of Biological Science 21(2): 17-27. 
35. Hagan, D., Dobb, C., Timilsina, N., Escobedo, F., Toor, G. and Andreu, M. (2010). Anthropogenic effects on the physical and chemical properties of subtropical urban soils. Soil Use and Management 28: 78-88.

36. Mbaga, H. R., Msanya, B. M. and Mrema, J. P. (2017). Pedological characterization of typical soil of Dakawa Irrigation Scheme, Mvomero District, Morogoro Region, Tanzania. International Journal of Current Research in Plant Biology 4(6): 77-86

37. Yatno, E. and Zauyah, S. (2008). Properties and management implications of soils formed from volcanic materials in Lembang area, West Java. Indonesian Journal of Agricultural Science 9(2): 44-54.

38. Brady, N. C. and Weil, R. R. (2008). The Nature and Properties of Soils. 13th Edn. Pearson Education, Inc. 965pp.

39. USDA, United States Department of Agriculture - NRCS, Natural Resources Conservation Service (2016). Soil bulk density/moisture/aeration. Soil quality kit-Education for educators. [climatesmartfarming.org/wpcontent/uploads/2016/.../Cornell-Farmework-Manual.pdf] site visited on 12/10/2017.

40. Cass, A. (1999). Interpretation of Some Soil Physical Indicators for Assessing Soil Physical Fertility. In: Soil Analysis: An Interpretation Manual. 2nd edition, (Edited by Peverill, K. I., Sparrow, L. A. and D. J. Reuter, D. J.). CSIRO Publishing, Melbourne. pp. 95-102.

41. Dalal, R. and Meyer, R. J. (1986). Long term trend in fertility of soils under continuous cultivation and cereal cropping in Queensland II. Total organic carbon and its rate of loss from soil profile. Australian Journal of Soil Research 24: 301-309.

42. De Geus, J. G. (1973). Fertilizer Guide for the Tropics and Subtropics, (Ed. 2). Cornell University. Centre d'etude de l'azote. $774 \mathrm{pp}$.

43. Busscher, W. J., Frederick, J. R. and Bauer, P. J. (2000). Timing effects of deep tillage on penetration resistance and wheat and soybean yield. Soil Sci. Soc. Am. J. 64: 999 - 1003.

44. Massawe, I. H., Msanya, B. M. and Rwehumbiza, F. B. (2017). Pedological characterization and fertility evaluation of paddy soils of Mvumi village, Kilosa District, Tanzania. International Journal of Current Research in Plant Biology 4(4): 49-60.

45. Hillel, D. (2007). Soil in the Environment: Crucible of Terrestrial Life. ${ }^{\text {st }}$ Edn. Academic Press/Elsevier, Amsterdam. ISBN: 9780123485366. 320pp.

46. Haghnazari, F., Shahgholi, H. and Feizi, M. (2015). Factor affecting the infiltration of soil: review. International Journal of Agronomy and Agricultural Research (IJAAR) 6(5): 21-35.

47. Dejarme-Calalang, G. M. and Colinet, G. (2014). A review of soils and crops in the Bukidnon Highlands of Northern Mindanao, the Philippines. Biotechnology Agronomy Society and Environment 18(4): 544-557.

48. Kimaro, D.N., Msanya, B.M., Mwango, S.B., Kimbi, G.G and Kileo, E.P. (2001). Land suitability evaluation for the production of the major crops in the Southwestern part of the Uluguru Mountains, Morogoro Rural District, Tanzania. Soils and Land Resources of Morogoro Rural and Urban Districts, Volume 2. Department of Soil Science, Faculty of Agriculture, Sokoine University of Agriculture, Morogoro, Tanzania. 95pp.

49. Gilkes, R. J. and Hughes, J. C. (1994). Sodium fluoride pH of south-western Australian soils as an indicator of P sorption. Australian Journal of Soil Research 32: 755-766.

50. Msita, H. B., Kimaro, D. N., Mtakwa, P. W., Msanya, B. M., Dondyene, S., Poesen, J. and Deckers, J. (2012). Effectiveness of miraba an indigenous soil and water conservation measures on reducing runoff and soil loss in arable land of western Usambara Mountains. In EGU General Assembly Conference Abstracts Vol. 14, 14122 pp.

51. Bremner, J.M. and Mulvaney, C.S. (1982) Total Nitrogen. In: Methods of Soil Analysis Part 2, $2^{\text {nd }}$ edit. (Edited by. Page, L.A., Miller, R.H. and Keeney D.R.), pp 595-624. ASA, SSSA Monograph no. 9, Madison, Wisconsin.

52. Tisdale, S. L., Nelson, W. L. and Beaton, J. D. (1993). Soil Fertility and Fertilizers. $6^{\text {th }}$ Edn. Prentice Hall, Upper Saddle, New Jersey. pp. 305-319.

53. Hodges, S. C. (2014). Soil Fertility Basics. Soil Science Extension North Carolina State University. 2007; [athttp//.plantstress. com/Articles/min_deficiency_i/soil_fertility.pdf] site visited on 7th May; 2018. 
International Journal of Advances in Scientific Research and Engineering (ijasre), Vol 5 (10), October-2019

54. Debicka, M., Kocowicza, A., Webera, J. and Jamroza, E. (2015). Organic matter effects on phosphorus sorption in sandy soils. Soil Science 62: 840-855.

55. Msanya, B. M., Wickama, J. M., Kimaro, D. N., Magoggo, J. P. and Meliyo, J. L. (1996). Investigation of the environmental attributes for agricultural development in Kitanda village, Mbinga District, Tanzania. Technical Report No 5. Department of Soil Science, Faculty of Agriculture, Sokoine University of Agriculture, Morogoro, Tanzania and Ministry of Agriculture, National Soil service, Agricultural Research Institute, Mlingano, Tanga, Tanzania. 38 pp.

56. Lal, R. and Shukla, M. K. (2004). Principles of Soil Physics. Marcel Dekker, Inc. New York. Basel. 716pp.

57. Msanya, B. M., Kimaro, D. N., Kileo, E. P., Kimbi, G. G., Munisi, A. I. M. (2001). Land Resources Inventory and Suitability Assessment for the Production of the Major Crops in the Eastern Part of Morogoro Rural District, Tanzania. Soils and Land Resources of Morogoro Rural and Urban Districts, Vol. 3. Department of Soil Science, Faculty of Agriculture, Sokoine University of Agriculture, Morogoro, Tanzania. 69pp.

58. Metson, A. J. (1961). Methods of Chemical Analysis for Soil Survey Samples. New Zealand Department of Scientific and Industrial Research. 102pp.

59. Edem, S. O. and Ndaeyo, N. U. (2009). Fertility status and management implications of wetland soils for sustainable crop production in Akwa Ibom State, Nigeria. Environmental Development Sustainability 11: 393-406.

60. Kileo, E. P. (2000). Land Suitability Assessment of the Wami Plains in Morogoro, Tanzania with respect to the production of the main food crops and extensive grazing. Thesis, for Award degree of MSc. at Sokoine University of Agriculture, Morogoro, Tanzania. 152pp.

61. Drever, J. I. (1994). The effect of land plants on weathering rates of silicate minerals. Geochimica et Cosmochimica Acta 58(10): 2325-2332.

62. Commission of the European Communities (1986). Council directive on the protection of the environment, and in particular of the soil, when sewage sludge is used in agriculture. Official Journal of the European Communities 181, 0006-0012.

63. Li, Y., Wang, Y. B., Gou, X., Su, Y. B., and Wang, G. (2006). Risk assessment of heavy metals in soils and vegetables around non-ferrous metals mining and smelting sites, Baiyin, China. Journal of environmental sciences (China), 18(6), 1124-1134.

64. Pasquini, M. W. (2006). The use of town refuse ash in urban agriculture around Jos, Nigeria: health and environmental risks. Science of the Total Environment 354(1): 43-59. 